length liberated to give origin in like manner to new discs, or to be appropriated in some other way.

6. From observation 4 it will be seen that the disc, or so called cytoblast, is originally a pellucid globule, which globules, therefore, is the true cell-germ.

7. Sometimes the quantity of the pellucid substance in the blood cell is very much increased. This takes place at the expense of the red coloring matter which surrounds it. The blood corpuscles, now cells, I have seen in various parts collected until the capillaries were completely filled with them, and until they had become pressed together into many-sided objects.

8. The originally colorless substance derived from the nuclei of the blood cells and nearly filling the capilaries, as I have found it, appears to constitute the essential part of coagulable lymph to organise the same, and to give origin to the tissues, \&c. It seems to be this same colorless substance derived from the nuclei of the blood cells that forms the exudation, corpuscles of authors, the fibres of false membrane, and the filaments in coagulating blood-filaments which, as I have shown, here and there arise while this substance is still within the cells.-Phil. Mag.

\section{REGISTRATION OF DEATHS.}

TO THE EDITORS OF THE PROVINCIAL MEDICAL JOURNAL.

Gentlemen, - I shall feel much obliged if you will inform the readers of the Provincial Medical Journal that the Registrar-General has recently given the following directions to the registrars of deaths :-

"When the information given to you by the medical attendants upon deceased persons, respecting the ' cause of death,' contains also a statement of the duration of the fatal diseases, or is accompanied by the memorandum ' $(p$. mort $)$ ' denoting that the nature of the causes of death had been ascertained or verified by a post-mortem examination, you will not fail to enter these statements in the column of the register, headed " cause of death."

It is desirable on many accounts that the laws respecting the duration of diseases should be ascertained, and this will afford the medical profession an opportunity of entering on permanent records a suffi. cient number of observations for determining those laws as well as the laws of mortality.

With regard to the registration of the "causes of death," it has been found the most convenient and satisfactory course for the medical attendant to leave a written certificate with the friends of the deceased person, to be placed in the hands of the registrar.

The registrar is directed to ask the informant whether any written statement of the cause of death has been left by the medical attendant; but the relatives, from the natural distraction of grief, or ignorance of its scientific importance, are apt to forget the medical certificate, unless the medical attendant take the trouble to state that it will be required, and place it in their hands.

If the medical profession needed any stimulus to induce them to contribute to the promotion of medical science, or to the discovery and consequent removal of the causes of untimely death, it will be found in the following considerations, to which the RegistrarGeneral has adverted in his last report :-

"I hope that the members of the medical profession, who have hitherto given their aid, will cordially assist in carrying out this national registration of the causes of death, as they alone are able to give a correct statement of the nature of the fatal diseases; and to them, more than to the members of any other profession, must be apparent the vast importance of thus collecting accurate materials for advancing the science of vital statistics."

Copies of the "Statistical Nosology, with notes and observations for the use of those who return the causes of death," may be procured by any medical practitioner, upon application (verbal or written) at the General Register-office.

I have the honor to be, Gentlemen, Your obedient servant, William Farr.

General Register-office, May 6, 1843.

\section{PROPOSED PLAN FOR REGISTRATION OF DEATHS.}

TO THE EDITORS OF THE FROVINCIAL MEDICAL JOURNAL.

Gentlemen,-I beg to forward to you the following correspondence with the Registrar-General upon the subject of registration of deaths.

My object in requesting a place in your Journal for these letters is, that of calling the attention of my professional brethren throughout the kingdom to the great importance of adopting one or other of the proposed plans, so as to ensure a correct return in every instance of the actual cause of death.

The plan mentioned by the Registrar-General would be all-sufficient, if it could be relied upon, which it cannot. At all events it is quite clear that the returns, as at present made, are of trifling value compared with that which would be attached to them were the sources of information derived from the right quarter; and I hope you will join with me in calling upon my professional brethren to assist in this great national undertaking.

I am, Gentlemen, Your obedient servant,

Stowmarket, May 9, 1843.

C. R. Brea.

\section{(Copy.)}

Stowmarket, May 6, 1843.

Sir,-In your fourth Annual Report I find an article upon Statistical Nosology, in which a list of various names of diseases returned to you as the causes of death is inserted. This article, published in a separate form, has been kindly sent me by the deputy registrar of this town, and I presume has been done to other medical men, under the impression that these terms have been returned by them as the cause of death. For the honor of the medical profession I have no hesitation in stating that such returns were never made by its members. You will not, I am sure, Sir, consider this a bold assertion, when I state that I have very rarely indeed been applied to, to supply the registrar with the cause of death. In the district 
which $I$ attend as medical officer of the Stow union, I cannot remember being asked for such information in a single instance, and in the others not half a dozen times since the act has been in operation. The effect of this is obvious. The deputy registrar is generally ignorant of medical terms, and inserts as the cause of death in his return any name, however absurd, which the friends of the deceased or his own imagination supply him with. Hence we have such returns as the following, which it is obvious would not have been returned by educated medical men:- "bad mouth," " bile on the stomach," " black cramp," " bowel hives," "chance medley," "crick," "croak," "decay of blood," "flox," " frog," "frox," " glands," " hives," " morbosity," " navel string," " paroxysm,", " planet stroke,"," rising of the heart," " rising of the lights," " thrift," " water," " water complaint," " watery gripes," \&c. \&c.

I need not say a word, Sir, I am sure, to convince you that such a parody upon our nosology was never made by members of the medical profession. If, then, the error is obvious here, how much more likely is it to have extended to the diseases whose fatal frequency makes the popular appellation correct, although their application is as frequently the reverse? How often do we hear the words "consumption," "decline," " the fever," or " the evil," applied to diseases which belong not to our nosology. Nine poor people out of ten in this neighbourhood will give you one of the above, or else "an inflammation," as the cause of almust every death which occurs. I have been induced, Sir, to make these observations, because I feel the immense importance of the subject you have taken up with such praiseworthy zeal, and because I think I can suggest a simple remedy to obviate the difficulty, and ensure a more correct return in future. Permit me to state, Sir, that I am quite certain the medical profession will unanimously come forward and assist you in the great national undertaking of obtaining correct data upon which tabular views of the causes of death can be framed. The remedy which I would propose is that of making every medical man in the kingdom registrars of mortality. This can easily be done by issuing blank forms, similar to the one enclosed, to the registrar of every district, with directions to supply copies to the medical men, with a request that they might be filled up every month, quarter, or half-year, and delivered to him duly signed. I am quite sure that a majority of the profession would do this without any fee or greater reward than the consciousness of aiding an increasingly important branch of medical statistics.

I have the honor to remain, Sir, Your obedient servant,

C. R. BreE.

The Registrar-General.

ANSWER FROM THE REGISTRAR-GENERAL. (Copy.)

Sir,-I have to return you my best thanks for the suggestion which you have been so obliging as to make in your letter of the 6th instant.

What I wish to impress upon the medical gentlemen throughout the country is, the expediency for them to acquire the habit, even when unsolicited, of leaving with the friends of the deceased patient a brief statement of the cause of death, to be by them given to the registrar.

This is alluded to in a letter lately published in some of the medical journals, addressed to them by Mr. Farr; and it will always afford me pleasure to see that system recommended in the public journals for adoption generally by the medical profession.

I have the honor to be, Sir, Your faithful servant, George Graham, Registrar-General.

C. R. Bree, Esq.

Table of Mortality in the Practice* of Mr. A. B., or Dr. A. B., residing at —-, in the County of from 184 to 184 .

\begin{tabular}{|c|c|c|c|c|c|c|c|c|c|}
\hline No. & $\begin{array}{l}\text { Name in } \\
\text { full. }\end{array}$ & Age. & Occupation & Residence. & $\begin{array}{l}\text { Nature of } \\
\text { Patient's } \\
\text { Locality. }\end{array}$ & $\begin{array}{l}\text { Name of } \\
\text { Disease. }\end{array}$ & $\begin{array}{l}\text { Duration } \\
\text { of Illness. }\end{array}$ & Date. & General Remarks. \\
\hline & & & & & 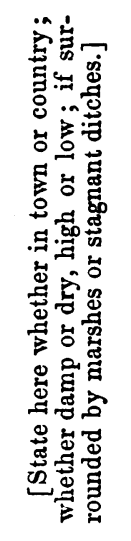 & 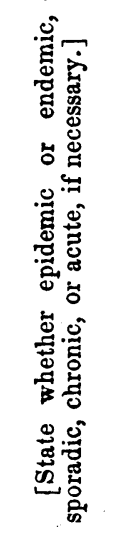 & & & . \\
\hline
\end{tabular}

* Hospital, workhouse, or gaol. 